\title{
Three new ascomycetes on epiphyllous liverworts
}

\author{
PETER DÖBBELER
}

DÖBBELER, P. 2016: Three new ascomycetes on epiphyllous liverworts. - Karstenia 56: 47-54. HELSINKI. ISSN 0453-3402.

The leaves of vascular plants in tropical rainforests are often covered by liverworts that form the substrate for many highly-adapted parasitic ascomycetes. Whilst looking for these fungi three new species were discovered. Bryothele biporosa has porous ascospores and develops on and between the leaves of Radula flaccida in tropical America. Bryothele was hitherto known only from B. mira on the same host species in tropical Africa. Epibryon platycarpum forms tiny semiglobose ascomata on the dorsal leaf surfaces of Radula sp. in Cameroon. Epibryon semitectum has ascomata partly protected by the leaf margins. It infects Cyclolejeunea peruviana in Costa Rica. Like most hyperepiphyllous ascomycetes, these new species are biotrophic parasites.

Key words: biotrophic parasites, hepaticolous, hyperepiphyllous, phyllosphere, Bryothele, Epibryon.

Peter Döbbeler, Ludwig-Maximilians-Universität München, Fakultät für Biologie, Systematische Botanik und Mykologie, Menzinger Str. 67, D-80638 München, Germany; e-mail:doebbeler@lrz.uni-muenchen.de

\section{Introduction}

The presence of bryophytes on the surface of living leaves of vascular plants is one of the most typical features of tropical rainforests (Frahm et al. 2003). Epiphyllous liverworts are the substrate for many obligately parasitic ascomycetes. They form a systematically heterogeneous assemblage representing numerous unrelated lineages. Currently, more than 30 species of hyperepiphyllous ascomycetes are known from tropical America, Africa, and Asia. Almost all occur on liverworts like Radula spp. (Radulales) and especially Lejeuneaceae (Porellales). About three quarters of the species belong to the Hypocreales (Döbbeler 2017). Screening liverwort-covered leaves from remote tropical regions has revealed that many taxa still remain to be described. Three new non-hypocrealean species are presented here.

\section{Material and methods}

Dry herbarium material was analyzed using standard techniques. All measurements, apart from ascomatal size, were made in lactophenol cotton-blue (CB). Iodine reactions were tested with Lugol's solution (LUG). 


\section{Results and discussion}

\section{On the genus Bryothele}

The genus Bryothele was described by the author and placed into Dothideomycetes, incertae sedis (Döbbeler 1998). Bryothele mira, a biotrophic parasite on the epiphyllous liverwort Radula flaccida Lindenb. \& Gottsche in tropical Africa, was initially the only species in the genus. A novel neotropical pendant has now been discovered on the same host species but in tropical America - the proposed B. biporosa. Both species have rather large, black ascomata that are easy to detect because they contrast against the light green colour of the apparently unaffected host plants. Ascomatal, hymenial and mycelial features, including the dark, two-celled ascospores with light apertures, occur in a unique combination not known elsewhere among bryophilous fungi. Hyperepiphyllous ascomycetes develop under the same ecological conditions as their delicate and short-lived hosts in the phyllosphere. They typically have tiny, soft and hyaline or palecoloured ascomata with small, nearly colourless, thin-walled ascospores (Döbbeler 1998, 2017). Carbonaceous excipula and intensely coloured ascospores with weak points are more typically found in harsh environments than in perpetually warm and humid lowland rainforests.

The systematic position of Bryothele within the Dothideomycetes is not clear. Some features are reminiscent of foliicolous ascomycetes of the genus Meliolina Syd. \& P. Syd. (Dothideomycetes, incertae sedis) that colonize leaves of myrtalean hosts in the Old World tropics. Bryothele mira and Meliolina spp. have similar ascomata, asci and interascal tissues, as well as possessing light circular transverse bands within the brown spore walls. However, Meliolina ascospores are consistantly three-septate and differ further by having up to eight bands. The mycelium consists of superficial, brown hyphae sometimes forming mats. Appressoria enter the host's stomata (stomatopodia) and pale intercellular hyphae are present. Intracellular haustoria are unknown in $\mathrm{Me}$ liolina (Hughes 1993), but formed in Bryothele.

The pre-formed, unpigmented, thinner regions of the spore wall in both Bryothele species are regarded as germ slits or germ pores. Hyphae have repeatedly been observed arising from the weak points in the walls of discharged B. mira spores as they lie on the host leaves (Döbbeler 1998). Germ tubes in Meliolina coming out of the pale bands were also noticed by Hughes (1993). Cannon (1993) suggests that the spore bands in a number of unrelated ascomycetes function most likely as germ slits.

\section{Bryothele biporosa Döbbeler, sp. nova} -Fig. 1a-c

\section{MycoBank no.: MB 818904}

Diagnosis: Very similar to B. mira but ascospores at both ends with a light pore; parasitic on epiphyllous Radula flaccida in tropical America.

Typus: Guyana. Paramakatoi Village, trails NW of village, submontane rain forest, $04^{\circ} 42^{\prime} \mathrm{N}$, $59^{\circ} 43^{\prime} \mathrm{W}, 500-800 \mathrm{~m}$ alt., epiphyllous in undergrowth, on Melastomataceae, associated with Epibryon hypophyllum, II.1996 Bernecker Lücking 842, Smithsonian Bryo-Lichenological Expedition to Guyana, ( $\mathrm{M}$ - holotype).

Etymology: bi- (in Lat. compounds) = two-, porosus $($ Lat.) $=$ provided with pores; refers to the ascospores.

Ascomata globose or ovoid to conical, black, without setae, (90-)120-150(-170) $\mu \mathrm{m}$ in the widest diam. Excipulum without recognizable cells when seen from above. Asci narrowly ellipsoidal to claviform, thick-walled, with a short, often bifurcate foot, 33-42 × (11-)13-15.5 $\mu \mathrm{m}$, (2-, 3-)4-spored. Iodine (LUG) negative. Ascospores ellipsoidal, 2-celled, both cells slightly asymmetrical, dark brown, (13.5-)14-18(-20) $\times$ (5-)6-7 $\mu \mathrm{m}$, at both ends with a light, inconspicuous, up to 2 um wide pore; epispore smooth. Hyphae colourless, thick-walled, superficially growing mostly over the anticlinal host cell walls, 1.5-4 $\mu \mathrm{m}$ wide. Haustoria intracellular, variable, often like a corkscrew or spiral, up to $10 \mu \mathrm{m}$ diam. Additional characters as in Bryothele mira. Anamorph not observed.

Host: Radula flaccida.

Known distribution: Costa Rica, Guyana. 
Bryothele biporosa matches B. mira in many characters including its excipular structure, hymenial and mycelial features, host selection, microniches occupied and type of parasitism. Essential differences concern the shape and position of the light wall perforations at both ascospore cells. The apertures are circular and subterminal in B. mira, pore-like and terminal in B. biporosa. Further differences regarding ascospore size may exist. In B. mira the asci are two- or three-spored and the ascospores somewhat larger than those of B. biporosa with mostly four-spored asci. However, spore size varies considerably even within one ascoma depending on the number of spores per ascus, e.g., a two-celled ascus of B. biporosa had large spores measuring 15-20 $\mu \mathrm{m}$.

Both Bryothele species occur on Radula flaccida, a liverwort with a bicontinental distribution in tropical Africa and America (Schuster 1980, Gradstein et al. 1983). This is the first documented example of two closely-related bryophilous fungi that occupy different geographical regions on one and the same host. However, screening density is very low.

Additional specimens examined: COSTA RICA. Without further information, 1987/1988, Döbbeler CR 725 (TUR), CR 728 (USJ). GUYANA. With the same label information as in the holotype specimen, but without phorophyte indication, Bernecker Lücking 836 (NY), 874 (M); trail NW of village towards Kato, submontane to lowland rain forest, epiphyllous on shrubs and trees, Bernecker Lücking 917 (NY).


Fig. 1, a-c. Bryothele biporosa $. \mathrm{a}=$ asci, the right one immature, $\mathrm{b}=$ ascospores, the right ones found on the leaf surface, $\mathrm{c}=$ superficial hyphae with intracellular, coiled haustoria. $\mathrm{d}$, e. Bryothele mira $. \mathrm{d}=$ mature asci, $\mathrm{e}=$ ascospores. $-\mathrm{a}-\mathrm{c}$ holotype, d, e Pócs et al. 97113/L. - both scales: $20 \mu \mathrm{m}$. 
Bryothele mira Döbbeler \& Melnik

- Fig. 1, d-e

Ascomata superficially on or between the leaves, (sub)globose, ovoid or conical, black, carbonaceous, without setae, $100-170 \times 100-130 \mu \mathrm{m}$. Ostiole small, irregularly bordered, not visible as a light spot in stereomicroscopic magnification. Excipulum without recognizable cells when seen from the outside; in section wall 15-20 $\mu \mathrm{m}$ thick, composed of thick-walled cells with small, tangentially extended, rounded lumina and merging walls, outer cells with very strong black thickenings. Interascal filaments to $2 \mu \mathrm{m}$ thick, with ramifications and anastomoses, connected to the inner excipular wall. Asci elongated ellipsoidal to claviform, thick-walled, $35-50 \times 8-16 \mu \mathrm{m}$, 2- or 3-spored; degenerating spores not recognizable; discharged asci cylindrical, two separating wall layers not discernible. Iodine (LUG) negative. Ascospores ellipsoidal, 2-celled, at the septum sometimes slightly constricted, cells usually asymmetrical, brown, becoming darker in $\mathrm{KOH},(14-) 16-20(-22) \times 6-8.5(-9.5) \mu \mathrm{m}$; wall at both ends with a light, transverse, thin-walled ring in subterminal position; epispore smooth; 1(2) spores often oriented with the thicker cell towards the ascus foot. Hyphae colourless, with walls up to $2 \mu \mathrm{m}$ thick, superficial, preferring the anticlinal host cell walls, 2.5-5(-7) $\mu \mathrm{m}$ thick. Haustoria intracellular, corkscrew-like, with up to 8 coils, up to $17 \times 9 \mu \mathrm{m}$ diam., rich in plasmatic content, connected to the hypha of origin by a delicate about $1 \mu \mathrm{m}$ wide hypha that perforates the host cell wall. Appressoria missing. Anamorph not observed.

\section{Host: Radula flaccida.}

Known distribution: Cameroon, Uganda, Comoros.

Ascomata develop individually or in small groups irregularly on and between or even below the host leaves and on the stems. Leaves may occasionally be perforated. The walls of leaf cells surrounding the ascomata are usually brownish and discoloured. Overmature, empty fruit-bodies persist for some time before they disappear. The type was collected from Comoros (Döbbeler 1998).
Additional specimens examined: CAMEROON. Southwest Province. Bimbia-Bonadikombo Forest Reserve (Mabeta-Moliwe Forest Reserve), lowland rainforest at sea level, 27.XI.2000 Franke (Döbbeler 8786, M). UGANDA. Rakai District. Buddu County: 1.4 $\mathrm{km}$ ENE of Katera village, $0^{\circ} 54,6^{\prime}$ ' S, 31 38 ,9' E, 1140 m alt., Piptadeniastrum-Uapaca type lowland rainforest, 9.IX.1997 Pócs, Lye \& Samuela 97113/L (EGR).

Epibryon platycarpum Döbbeler \& T. Franke,
$\begin{aligned} & \text { sp. nova } \\ & - \text { Fig. } 2\end{aligned}$

\section{MycoBank no.: MB 818905}

Diagnosis: Characterized by semi-globose ascomata up to 70 um diam., few, short setae, excipular margin with radially extended cells and 2-septate, 9-11 $\times 2.5-3 \mu \mathrm{m}$ large ascospores; parasitic on epiphyllous Radula sp. in Cameroon.

Typus: Cameroon. Southwest Province. Bimbia-Bonadikombo Forest Reserve (MabetaMoliwe Forest Reserve), lowland rainforest at sea level, $5000 \mathrm{~mm}$ annual precipitation, 27. XI. 2000, Franke (M - holotype Döbbeler 8780).

Etymology: platy- (in Gr. compounds) = broad, -carpus (in Gr. compounds) = -fruited; refers to the broad basal part of the fruit-bodies.

Ascomata superficially on the host leaves, semiglobose, dark brown to black, in transmitted light upper part dark caused by dark brown cells and setae, circularly surrounded by the lower lighter part, (45-)50-70(-75) $\mu \mathrm{m}$ diam., about $50 \mu \mathrm{m}$ high. Ostiole often with irregular radial fissures, ca. $12 \mu \mathrm{m}$ diam. Setae formed only in the upper region, irregular, straight or more often bent towards the substrate, thick-walled, up to $15(-25) \mu \mathrm{m}$ long, basally up to $3 \mu \mathrm{m}$ wide, sometimes almost missing; short setae with transitional forms to thick-walled, dark excipular cells. Excipulum apically with angular 2-4 $\mu \mathrm{m}$ wide cells, cellular structure often inconspicuous due to setae and dark wall thickenings, further down cells lighter, rather regularly, radially extended, up to $6(-9) \mu \mathrm{m}$ long and $2-3.5(-4.5)$ $\mu \mathrm{m}$ wide; excipular margin more or less fringed. Interascal filaments missing. Hymenial gelatine 
in iodine (LUG) reddish, after pretreatment with $\mathrm{KOH}$ bluish. Asci ellipsoidal, but variable in outline due to spore position, often only spore packets recognizable, sessile, (15-)17-25(-28) $\times(5-) 6-8(-9.5) \mu \mathrm{m}, 8$-spored, up to 25 mature asci per ascoma. Ascospores narrowly ellipsoidal to claviform, straight or slightly curved, with 2(3) delicate transverse walls, not constricted at the septa, colourless, halves asymmetrical; wall strongly cyanophilous (apart from overmature spores $), 9-11(-12.5) \times(2-) 2.5-3 \mu \mathrm{m}$. Hyphae as in E. semitectum, 1-1.5(-2) $\mu \mathrm{m}$ wide. Anamorph not observed.

Host: Radula sp. (The species will be described by Prof. Pócs as $R$. "camerunensis".)

Known distribution: Cameroon.

In most cases the ascomata develop singly at the dorsal surface of the host leaves. Infected plants or parts of them often show a reduced vitality, presumably not caused by fungal parasitism. In each of the five collections the host species
Radula sp. is associated with the less frequent $R$. flaccida. However, ascomata of Epibryon platycarpum were only observed on Radula sp. In the type collection, Psoroglaena hepaticicola (Döbbeler \& Vězda) H. Harada is additionally present. The verrucarialean lichen was hitherto known on $R$. flaccida from Tanzania and D. R. Congo (Zaire) (Döbbeler 1998).

Epibryon platycarpum is a distinct species defined by having very small, depressed ascomata attached to the dorsal surface of the host leaves by a broad base, a few short, vestigial irregular setae in the upper part of the ascomata, together with thick-walled, dark cells, radially elongated lighter cells in the lower excipulum that surround the darker part. The ascopores are 2-septate, up to $11 \mu \mathrm{m}$ long with cyanophilous walls. It is parasitic on epiphyllous Radula sp., but not $R$. flaccida.

Additional specimens examined: Four independent collections with the same label as the type specimen, leg. Franke: Döbbeler 8778 (B), 8779 (M), 8784 (NY), 8789 (TUR).



Fig. 2. Epibryon platycarpum. $\mathrm{a}=$ leaves (two with gemmae) colonized by one or two ascomata, $\mathrm{b}=$ ascomata seen from above, $\mathrm{c}=$ setae, $\mathrm{d}=$ structure of excipular margin, $\mathrm{e}=$ mature asci in outline, $\mathrm{f}=$ ascospores. $-\mathrm{a}, \mathrm{b}$ Franke (Dö 8779), c, d holotype, e, f Franke (Dö 8778). - a scale: $400 \mu \mathrm{m}$, b scale: $30 \mu \mathrm{m}$, c-f scale: $15 \mu \mathrm{m}$. 


\section{Epibryon semitectum Döbbeler, sp. nova}

- Fig. 3

MycoBank no.: MB 818906

Diagnosis: Characterized by subpyriform, nonsetose ascomata formed at the leaf margin, up to $120 \mu \mathrm{m}$ diam. and 3-septate, $15-17.5 \times 4-5 \mu \mathrm{m}$ large ascospores; parasitic on epiphyllous $\mathrm{Cyc}$ lolejeunea peruviana in Costa Rica.

Typus: Costa Rica. Prov. Limón. Atlantic coast, Parque Nacional Tortuguero, at sea level, 6. III.2008, Döbbeler 8677 (USJ - holotype; isotypes - M, NY).

Etymology: semi- (in Lat. compounds) = half-; tegere, tectus (Lat.) = cover, covered; refers to the ascomata partly covered by the leaf margin.

Ascomata at the leaf margin, subglobose, conical or pyriform, brown to black, upper part often darker due to small cells with thick walls and cap-like thickenings of the outer wall, without setae, $(80-) 90-120 \times(75-) 80-110 \mu \mathrm{m}$. Ostiole usually not seen as a light spot by stereomicroscopic magnification. Excipulum with textura angularis, cells in the middle and upper part 3-5 $\mu \mathrm{m}$ wide, in the lower part up to $7 \mu \mathrm{m}$ wide, sometimes with slightly sinuous walls, towards the apex outer cell walls with dense, papilliform, dark thickenings that obscure the tissue type and cause a warty surface in lateral view. Interascal filaments missing. Hymenial gelatine in iodine (LUG) reddish, after pretreatment with $\mathrm{KOH}$ bluish. Asci irregularly ellipsoidal depending on spore position, straight or bent, sessile, without apical structures, $(30-) 35-45(-50) \times(10-) 12-15$ $\mu \mathrm{m}, 8$-spored, few (up to 20) mature asci per ascoma; spores sometimes forming packets without recognizable ascus wall. Ascospores narrowly ellipsoidal, halves slightly asymmetrical, with 3(4) transverse septa, not constricted at the septa, light brown, (14-) $15-17.5(-18) \times(3.5-) 4-5 \mu \mathrm{m}$, irregularly lying in the asci; wall in developing spores for a long time cyanophilous, fully mature spore not or hardly reacting with $\mathrm{CB}$. $\mathrm{Hy}$ phae delicate, light brown, superficially on the host cells or somewhat immersed within the outermost cell walls, with ramifications and anastomoses, strongly preferring the anticlinal walls, imitating the host's cell net, (1-)1.5-2 $\mu \mathrm{m}$ thick, close to ascomata; 2(3) hyphae often growing side by side. Anamorph not observed.

Host: Cyclolejeunea peruviana (Lehm. \& Lindenb.) A. Evans.

Geographical distribution: Known only from the type collection.

The ascomata of E. semitectum usually develop singly at the margin of the host leaves in a peculiar position. They are not laterally fixed at the ventral leaf side as in Epibryon filiforme Döbbeler \& Menjívar or Bryonectria spp. and other species (Döbbeler 1998, 2002, 2017), but perpendicularly attached to the leaf lamina, resulting in upwards oriented fruit-bodies. About half of an ascoma is thereby protected by the leaf margin. Rarely, ascomata develop superficially on a leaf near the margin, perforate the leaf or lie between two subsequent leaves being attached to both. Greyish caps were repeatedly observed on ascomata. The caps are formed by light hyphae originating within the ascoma. In these cases the fruit-bodies were devoid of ascospores.

It is interesting to note that hyphae were regularly found growing on the disc-like gemmae of the host leaves. There can be no doubt that the fungus is asexually distributed together with its host.

Epibryon semitectum belongs to a small group of related species including E. hepaticicola (Racov.) Döbbeler s. 1. and E. hypophyllum Döbbeler. They share essential characters, such as having small fruit-bodies, a cellular excipulum, and ellipsoidal, colourless to light brown ascospores with three transverse septa. These species grow as biotrophic parasites on a number of terrestrial, corticolous and epiphyllous liverworts. Size of ascomata and ascospores, formation of setae, occupied microniche and presumably host selection play a role in species differentiation. It is currently unclear if occurrence on different hosts should be taxonomically expressed by narrower species concepts.

Epibryon hepaticicola and E. hypophyllum occur in the Northern hemisphere as well as in tropical rainforests. Epibryon hepaticicola is characterized by having globose, superficial ascomata ornamented with short, sometimes curved setae (Döbbeler 1978, 1998). Epibryon hypophyllum does not develop setae and forms 

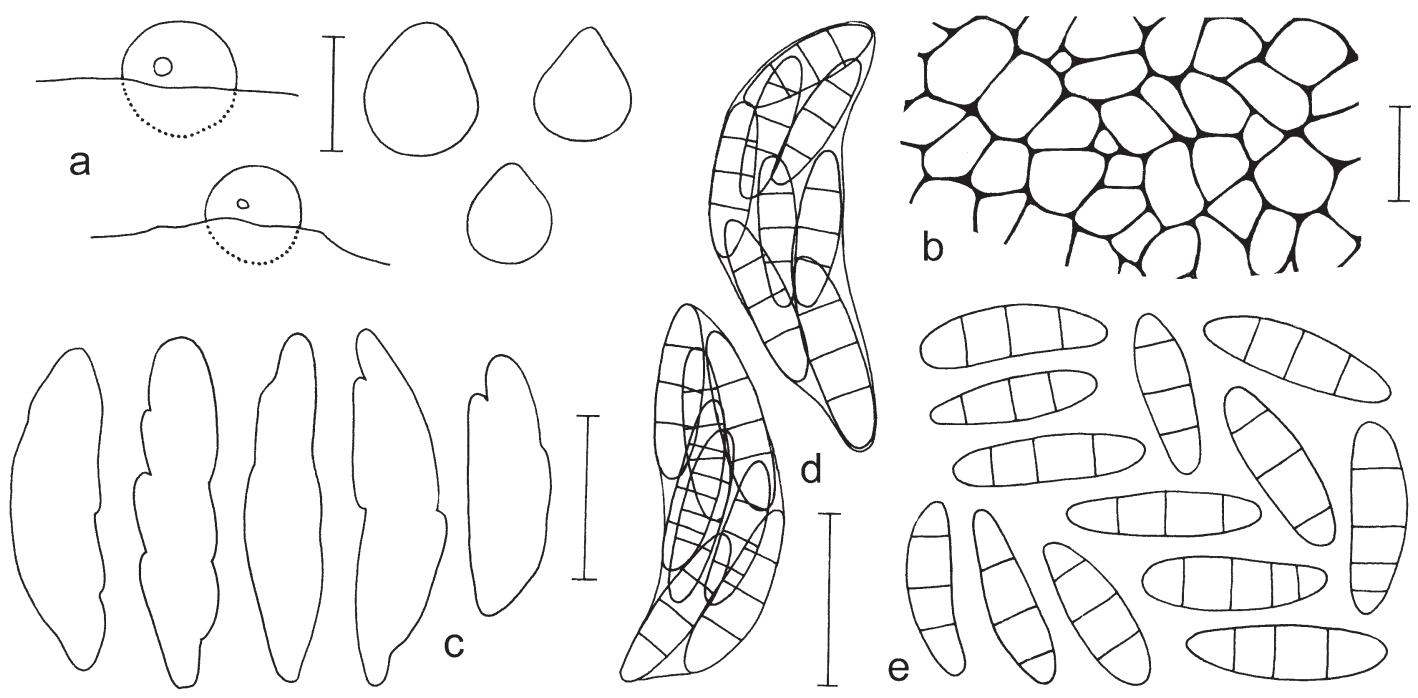

Fig. 3. Epibryon semitectum, holotype. a = two ascomata seen from above partly covered by the leaf margin and three ascomata laterally seen in outline, $\mathrm{b}=$ cells of lower excipulum, $\mathrm{c}=$ mature asci in outline, $\mathrm{d}=$ asci with mature ascospores, e = ascospores. - a scale: $100 \mu \mathrm{m}$, b scale: $5 \mu \mathrm{m}$, c scale: $20 \mu \mathrm{m}$, d, e scale: $15 \mu \mathrm{m}$.

its ascomata at the ventral leaf side using one host cell for leaf perforation (Döbbeler 1979, 1998). The new species, Epibryon semitectum, differs by having ascomata devoid of setae, excipular cells provided with papilliform wall thickenings, relatively large three-septate ascospores, and ascomata fixed at the leaf margin perpendicularly to the lamina of an epiphyllous liverwort.

Acknowledgements: I am grateful to Dr. Andrea Bernecker (Erbach, Alb-Donau-Kreis), Dr. Thassilo Franke (München), and Prof. Dr. Tamás Pócs (Eger) who have collected epiphyllous liverworts for me in various tropical regions.

\section{References}

Cannon, P.F. 1993: Ascomycetes with banded spores. The genus Rikatlia gen. nov. - Systema Ascomycetum 11: 83-93.

Döbbeler, P. 1978: Moosbewohnende Ascomyceten I. Die pyrenocarpen, den Gametophyten besiedelnden Arten. - Mitteilungen der Botanischen Staatssammlung München 14: 1-360.

Döbbeler, P. 1979: Moosbewohnende Ascomyceten III. Einige neue Arten der Gattungen Nectria, Epibryon und Punctillum. - Mitteilungen der Botanischen Staatssammlung München 15: 193-221.
Döbbeler, P. 1998: Ascomyceten auf der epiphyllen Radula flaccida (Hepaticae). - Nova Hedwigia 66: 325-373.

Döbbeler, P. 2002: Microniches occupied by bryophilous ascomycetes. - Nova Hedwigia 75: 275-306.

Döbbeler, P. 2017 (in press): Hypocrealean hyperepiphyllous ascomycetes. - Biosystematics and Ecology Series. Wien, Österreichische Akademie der Wissenschaften.

Frahm, J.-P. with contributions by Pócs, T., O’Shea, B., Koponen, T., Piippo, S., Enroth, J., Rao, P. \& Fang, Y.-M. 2003: Manual of Tropical Bryology. - Tropical Bryology 23: 1-195.

Gradstein, S.R., Pócs, T. \& Váňa, J. 1983: Disjunct Hepaticae in tropical America and Africa. - Acta Botanica Academiae Scientiarum 29: 127-171.

Hughes, S.J. 1993: Meliolina and its excluded species. Mycological Papers 166: 1-255.

Schuster, R.M. 1980: The Hepaticae and Anthocerotae of North America, Vol. IV. - Columbia University Press: New York. 
